\title{
Минская группа ОБСЕ: уроки прошлого и задачи на будущее
}

\author{
Филип Ремлер, Ричард Киракосян, Марина Лоренцини, Сергей Растольцев*
}

\section{Аннотация}

Международное сообщество, действуя через Минскую группу ОБСЕ, не смогло побудить лидеров Армении и Азербайджана к урегулированию карабахского конфликта, начавшегося в 1988 году и вылившегося в новый виток военных действий в сентябре 2020 года. Лидеры и население с обеих сторон выдвигали все более максималистские требования. Любого лидера, готового пойти на компромисс, могли объявить предателем. Боевые действия 2020 года кардинально изменили положение на местах. С помощью Турции Азербайджан вернул бо́льшую часть земель, утраченных предыдущим поколением. Но Азербайджан был вынужден разрешить России развернуть крупные миротворческие силы, чему он сопротивлялся в течение 25 лет. И хотя авторитет Минской группы ослаблен, она может сыграть роль в восстановлении доверия и связей между сторонами, открытии границ и, в конечном счете, возглавить переговоры о будущем статусе региона.

Ключевые слова

Карабах, Азербайджан, Армения, Россия, Турция, ОБСЕ.

Для цитирования этой публикации: Ремлер Ф., Киракосян Р., Лоренцини М. Д., Растольцев С. Минская группа ОБСЕ: уроки прошлого и задачи на будущее // ОБСЕ Insights 6. - Баден-Баден: Номос, 2021. URL: https://doi.org/10.5771/9783748921264-06

* Филип Ремлер, Фонд Карнеги за международный мир, Philip.Remler@ceip.org Ричард Киракосян, доктор наук, Центр региональных исследований, Армения, director@regional-studies.org Марина Дольчетта Лоренцини, Флетчеровская школа, университет Тафтс, США, marina.lorenzini@tufts.edu

Сергей Растольцев, ИМЭМО РАН, Россия, sergej-ras@yandex.ru 


\section{Введение ${ }^{183}$}

Военные действия, начавшиеся между Азербайджаном и Арменией 27 сентября 2020 года, еще раз напомнили миру, что на протяжении более чем тридцати лет карабахский конфликт не поддается урегулированию ${ }^{184}$. С 1992 года Минская группа ОБСЕ является международным органом, официально уполномоченным на осуществление посредничества. В течение всего этого времени она вела серьезные переговоры, но оказалась неспособной убедить лидеров Азербайджана и Армении пойти на взаимные уступки, необходимые для достижения мира. Недавние интенсивные военные действия изменили положение на местах, ослабили роль Минской группы и поставили под сомнение ее работу в будущем. В настоящей статье рассматриваются причины прошлых неудач и перспективы будущей деятельности Минской группы.

Статья состоит из четырех разделов. В первом анализируются стратегии, которым противостоящие стороны следовали в ходе переговоров в рамках Минской группы, начиная с прекращения огня в 1994 году и заканчивая возобновлением военных действий 27 сентября 2020 года. Во втором рассматривается деятельность Минской группы на протяжении этого периода. В третьем разделе анализируются цели и реакция основных заинтересованных сторон после 27 сентября 2020 года. В четвертом разделе - некоторые параметры, которые будут определять перспективы урегулирования в будущем.

\section{Переговорные стратегии после прекращения огня 1994 года}

Чтобы понять, почему 27 сентября 2020 года Азербайджан начал наступление, мы должны понять цели сторон в ходе военных действий начала 1990-х годов и их задачи после прекращения огня.

\section{Армения}

Первоначальной целью карабахского движения был «миацум»- объединение Нагорного Карабаха с советской Арменией путем его официальной передачи из состава советского Азербайджана. После распада Советского Союза эта четко сформулированная цель была заменена требованием независимости от Азербайджана, хотя желание объединиться с Арменией осталось. Армянские силы одержали победу в боях, которые начались в 1988 году и к 1992 году разрослись до полномасштабных военных действий. Армяне вытеснили азербайджанские силы из Нагорного Карабаха, захватили Шушу, которая на протяжении веков была укрепленным опорным 
пунктом азербайджанской власти в Карабахе, оккупировали буферную зону, прилегающую к региону, изгнали жителей и отразили азербайджанские контрнаступления. Нагорный Карабах добился фактического отделения от Азербайджана, однако прекращение огня в 1994 году (Бишкекский протокол) не привело к политическому урегулированию. В резолюциях Совета Безопасности ООН Карабах до сих пор рассматривается как часть Азербайджана ${ }^{185}$.

Районы в окрестностях Карабаха, захваченные в то время армянскими силами, делятся на три категории.

Территории между Нагорным Карабахом и Арменией: Лачинский и Кельбаджарский районы, в 1920-е годы - Курдистанский уезд или советский Красный Курдистан. Лачинский район был занят в мае 1992 года через несколько дней после взятия Шуши. Кельбаджарский район был захвачен в марте-апреле 1993 года. В результате боевых действий с этой территории было вытеснено как курдское, так и азербайджанское население. Армения и Нагорный Карабах считали эти районы жизненно важными, так как они обеспечивали наземные транспортные коммуникации между ними.

Территории между Нагорным Карабахом и Ираном: падение Кельбаджара привело к революции в Азербайджане. Летом 1993 года армянские войска начали наступление, в результате которого были захвачены Кубатлинский, Зангеланский и Джебраильский районы. Их жители были изгнаны. Данный регион, расположенный к югу от Карабаха до реки Аракс и граничащий с Ираном, считался стратегически важным.

Территории, расположенные к востоку от Нагорного Карабаха: тогда же, летом 1993 года армянские войска заняли стратегически важный город Агдам и часть Физулинского района. Города были разграблены, постройки разобраны на стройматериалы, уцелела лишь незначительная часть инфраструктуры, а линия фронта была заминирована для предотвращения азербайджанского контрнаступления. На переговорах армянская сторона считала эти районы самой легкой и дешевой разменной монетой.

Цель армянской стороны заключалась в сохранении как можно большей части территориальных завоеваний. Между тогдашним президентом Армении Левоном Тер-Петросяном и сторонниками жесткой линии как в Нагорном Карабахе, так и в Армении возникли разногласия относительно стратегии действий. Тер-Петросян и его сторонники считали, что успеха можно было добиться только путем обмена некоторых из оккупированных Арменией районов на мирное соглашение, которое обеспечило бы безопасность и статус Нагорного Карабаха с учетом перспективы наращивания финансовых и военных возможностей Азербайджана в будущем ${ }^{186}$. Сторонники более жесткой линии полагали, что Армения не должна идти на уступки и что ее задача заключается в сохранении статус-кво и в то же время в затягивании переговорного процесса до тех пор, пока международное сообщество и Азербайджан не признают независимость Нагорного Карабаха. 
Этот внутренний раскол усложнил для армянского руководства ведение переговоров с Азербайджаном. Значительная часть населения поддерживала сторонников «жесткой линии» и выступала против компромисса. Убийства и угрозы насилия блокировали движение к компромиссу и способствовали саботажу согласованных лидерами договоренностей ${ }^{187}$. После подписания перемирия 9 ноября 2020 года премьер-министр Армении Никол Пашинян признал: «Когда я подписывал этот документ, я понимал, что вероятность моей личной гибели очень высока не только в политическом, но и в физическом смысле» ${ }^{188}$. В 1999 году боевики ворвались в парламент и убили ряд руководителей страны и ключевых законодателей, обеспечив тем самым провал плана мирного урегулирования. После этого армянские лидеры на переговорах медлили, надеясь, что международное сообщество в конечном итоге деюре согласится с фактическим положением дел.

\section{Азербайджан}

Азербайджанские лидеры столкнулись с противоположной проблемой. В то время как Армения стремилась затягивать переговоры до тех пор, пока фактическое положение не будет признано де-юре, Азербайджан стремился изменить ситуацию и добиться того, чтобы сложившееся положение никогда не получило международного признания. Нынешний президент Ильхам Алиев, как и его армянские коллеги, опасался внутриполитической дестабилизации, если он отступит от максималистских территориальных требований.

Самый непосредственный способ изменения положения дел на местах - военные действия, и Азербайджан с этой целью последовательно выделял значительные ресурсы на укрепление своих вооруженных сил. Другая стратегия изменения ситуации предусматривала мобилизацию давления международного сообщества на Армению с целью вынудить ее пойти на уступки в ходе переговоров. В 1990-е годы азербайджанцы надеялись, что их нефтегазовые ресурсы заставят Запад оказать давление на Армению. Однако после разочаровывающих результатов переговоров в США (Ки-Уэст, 2001) и Франции (Рамбуйе, 2006) азербайджанское руководство, очевидно, пришло к выводу о том, что только Россия может повлиять на армян. Бряцание оружием, настойчивое стремление Азербайджана держать на линии фронта снайперов и тяжелые вооружения, а также наступление в апреле 2016 года были направлены на то, чтобы напоминать международному сообществу в целом и России в частности, что ситуация нестабильна и что необходимы конкретные действия, чтобы заставить армян пойти на уступки. Однако ни одна из этих стратегий не принесла Азербайджану желаемые результаты. 


\section{Деятельность Минской группы с 1992 года}

Деятельность созданной в 1992 году Минской группы ОБСЕ делится на три этапа. Первый (1992-1998) был отмечен стремлением Москвы обойти ОБСЕ и не позволить западным державам сдерживать Россию. В 1994 году, когда военные действия зашли в тупик, сильный первый российский переговорщик в Минской группе Владимир Казимиров без оглядки на западных посредников начал переговоры о прекращении огня на встрече в рамках Содружества Независимых Государств (СНГ) в Бишкеке, целью которых было вопреки ожидаемым возражениям Запада обеспечить развертывание миротворческих сил под руководством России. Азербайджан отказался и позднее подписал в Баку документ о прекращении огня, не предусматривавший создание какого-либо миротворческого механизма.

В 1997 году Франция и США присоединились к России в качестве сопредседателей Минской группы, а Казимиров был заменен другим представителем России. Сопредседатели совместно подготовили проект мирного урегулирования, в котором промежуточные решения и окончательный статус Карабаха рассматривались отдельно друг от друга (отсюда и название - план «поэтапного урегулирования»). Президенты Армении и Азербайджана Тер-Петросян и Гейдар Алиев приняли этот план, представленный в июле 1997 года. При этом ни у кого не было иллюзий относительно возможности достичь соглашения о статусе. Обе стороны считали, что соглашение, которое они подпишут, предоставит Армении фактический постоянный протекторат над Нагорным Карабахом в обмен на возвращение Азербайджану оккупированных территорий. Алиев полагал, что эта сделка отодвинет карабахскую проблему, которая привела к свержению пяти прежних лидеров его страны, на задний план политической повестки дня. Данная сделка вписывалась и в стратегию ТерПетросяна, предусматривавшую достижение соглашения с Баку прежде, чем Азербайджан сможет реализовать свои нефтяные богатства. Но Тер-Петросян, столкнувшись с внутренней оппозицией, был вынужден в марте 1997 года назначить лидера Нагорного Карабаха Роберта Кочаряна на пост премьер-министра Армении. Последний сторонник Тер-Петросяна, контролировавший силовые ресурсы, - министр обороны Вазген Саркисян - отвернулся от него, не согласившись с планом поэтапного урегулирования. В январе 1998 года сторонники жесткой линии, контролировавшие к тому времени все силовые структуры, вынудили Тер-Петросяна уйти в отставку. Президентом стал Кочарян, премьер-министром - Саркисян, отвергнувшие предложенный ОБСЕ план урегулирования 189 .

Второй этап (1998-2005) начался с переговоров между Кочаряном и Алиевым, которые держали их в секрете не только от общественности, но и от руководящего звена двух стран. В 1999 году Кочарян и Алиев устно согласовали свой собственный план: обмен территориями, в результате которого присоединение Нагорного Карабаха к Армении было бы признано де-юре, а к Азербайджану отошла бы часть территории Армении вдоль границы с Ираном, отделяющая Азербайджан от его на- 
хичеванского эксклава. Осенью 1999 года они проинформировали сопредседателей Минской группы об этом плане и попросили оформить его в письменном виде. Буквально через несколько недель, 27 октября 1999 года, боевики-экстремисты захватили парламент Армении и убили несколько занимавших высокие посты в правительстве политиков, включая премьер-министра Саркисяна и председателя парламента Карена Демирчяна. В результате Кочарян информировал Минскую группу об отказе от достигнутой договоренности. Сопредседатели Минской группы пытались спасти план, изменив его положения с учетом интересов Армении. Сохранив пункт о передаче Армении Нагорного Карабаха, они вместо обмена территорий предложили Азербайджану выделить транспортный коридор, который соединил бы с ним Нахичевань. Но такое изменение было неприемлемо уже для Азербайджана, и Алиев отверг данный план на переговорах в Ки-Уэсте в 2001 году. Алиев, всю жизнь укреплявший опору своей личной власти в Азербайджане, умер в 2003 году. Его сменил сын Ильхам Алиев, политическая поддержка которого за пределами его собственного клана была недостаточно прочной. Старший Алиев мог быть уверен в том, что переживет народные волнения, если пойдет на уступки. Младший - нет. После этого ни Азербайджан, ни Армения не могли пойти на реальные компромиссы.

На третьем этапе, начиная с 2005 года и до настоящего времени, стороны вернулись к обсуждению сокращенного варианта поэтапного урегулирования, оформленного в виде краткого документа с изложением «принципов», в конечном итоге положенных на бумагу и представленных сторонам в Мадриде в конце 2007 года. В «Мадридских принципах», преследовавших цель спасти переговорный процесс, предусматривались возвращение некоторых оккупированных территорий, временные гарантии безопасности Нагорного Карабаха от военных действий Азербайджана и, в конечном итоге, - весьма расплывчатое положение о том, что окончательный статус будет определен на основе «имеющего обязывающий характер волеизъявления народа». Такая договоренность по вопросу о статусе должна была открыть путь к возвращению оккупированных территорий.

Дмитрий Медведев, будучи президентом России (2008-2012), предпринял немало усилий для посредничества между его армянским и азербайджанским коллегами Сержем Саргсяном и Ильхамом Алиевым. Россия начала доминировать в переговорном процессе с согласия США и Франции, которые не были готовы инвестировать в переговорный процесс на таком высоком политическом уровне. После 1997 года Минская группа была редким примером сотрудничества России и Запада. Она и поныне остается исключением, несмотря на напряженность в отношениях между ее участниками, возникшую в связи с Украиной, Сирией и другими проблемами. Впрочем, в какой-то мере причиной этого успеха стало желание США и Франции, начиная с 2008 года, уступить России инициативу в группе.

Саргсян и Алиев продолжали встречаться, чтобы угодить Медведеву, но в действительности ни тот, ни другой не был заинтересован в достижении компромиссной договоренности, которая вызвала бы протесты населения обеих стран. Несмот- 
ря на российский оптимизм перед саммитом в Казани в 2011 году, когда президентов пытались убедить подписать соглашение хотя бы по нескольким принципам, Алиев и Саргсян отказались. «Казанская формула» (последний, сильно сокращенный вариант «Мадридских принципов»), хотя и часто цитируемая, оказалась мертворожденной, несмотря на то, что ее отдельные положения сохраняют свою актуальность. Минская группа погрузилась в спячку, которая продолжалась во время азербайджанского наступления 2016 года, революции в Армении 2018 года и военных действий 2020 года. Во время этих событий в роли главного посредника выступала Россия, одной из основных целей которой, по-видимому, было развертывание российских миротворческих сил - именно этого Россия добивалась в 1994 году.

Таким образом, в течение последних двадцати лет - с тех пор как экстремисты сорвали сделку, заключенную Кочаряном и Алиевым, - стороны занимались, по определению одного из российских переговорщиков, «симулякром» переговоров. Частью этой шарады стало ритуальное обвинение Минской группы в неспособности добиться компромисса, к которому в действительности не были готовы сами стороны конфликта. Минская группа смирилась с этим, понимая, что предоставление двум лидерам политического прикрытия важно для достижения компромиссов, необходимых для достижения мира. На деле же получилось так, что поскольку сопредседатели Минской группы не дистанцировались от лидеров Армении и Азербайджана, группа обеспечила политическое прикрытие, позволявшее им уклоняться от мирного урегулирования конфликта. Посредники не могут заключить мир, это должны сделать сами воюющие стороны. Лидеры обеих сторон загнали себя в угол: пообещав добиться выполнения максималистских требований, не оставлявших места для компромиссов, они убедили свое население в том, что компромисс - это измена. Лидеры и сами подстроились под эти настроения. В начале 1993 года Гейдар Алиев, все еще находившийся в изгнании в своей родной Нахичевани, мог в частной беседе сказать американскому послу: «Даже когда Карабах был у нас, он не был нашим». Сегодня его сын повторяет единственный лозунг «Карабах - это Азербайджан» и заявляет, что Азербайджан не предложит Карабаху «широкую автономию», которую он когда-то обещал региону ${ }^{190}$.

Еще один важный аспект усилий ОБСЕ, который следует отметить: в 1996 году действующий Председатель назначил личного представителя, который должен был находиться в регионе в отличие от сопредседателей Минской группы, которые навещали регион нерегулярно. В течение 24 лет эту роль исполнял посол Анджей Каспшик. В отсутствие миротворческих сил или постоянной наблюдательной миссии бюро Каспшика осуществляло бо́льшую часть той незначительной деятельности по наблюдению, которая осуществлялась в зоне конфликта, направляя краткосрочные миссии на ограниченные участки по обе стороны от линии соприкосновения. Однако так как это происходило лишь с предварительного разрешения сторон, результаты данной деятельности были очень ограниченными. 


\section{Политические последствия недавних военных действий}

Наступление, начатое Азербайджаном в сентябре 2020 года, стало продолжением двух стратегий, которым он следовал на протяжении многих лет с целью изменить сложившееся положения дел: возвращения территорий и мобилизации международного давления на Армению. Заняв оккупированные территории, Азербайджан лишил бы Армению козырей на последующих переговорах. При военном содействии Турции Азербайджан добился большего успеха, чем ожидалось. Стремительно продвигаясь вглубь четырех районов, 7 ноября азербайджанская армия взяла горную крепость Шуша в самом сердце Нагорного Карабаха, получив возможность обстреливать столицу Степанакерт и перерезать Лачинский коридор - дорогу, соединяющую Степанакерт с Арменией ${ }^{191}$.

Вторая стратегия Азербайджана предполагала мобилизацию международного давления на Армению. Угрожая более широкой войной и еще большей нестабильностью вблизи российских границ, азербайджанское руководство побуждало Россию оказать давление на Армению. Этого удалось добиться вследствие успешной военной кампании. Реализация обеих стратегий стала возможной благодаря поддержке Турции, которая оказала военное содействие, предоставив, в частности, боевые беспилотники Bayraktar TB2, изменившие соотношение сил в ходе боевых действий, и обеспечила дипломатическую поддержку для усиления давления Алиева на Россию ${ }^{192}$. Турция переправила наемников из Сирии в Азербайджан и разместила в Гяндже самолеты F-16. Их присутствие не имело большого значения в военном плане, но недвусмысленно давало России понять, что может произойти, если все выйдет из-под контроля ${ }^{193}$.

Ответная реакция России, сформулированная в заявлении министра иностранных дел Лаврова 14 октября ${ }^{194}$, заключалась лишь в предложении заморозить ситуацию и обещании вернуть Азербайджану пять районов, к возвращению которых он и без того был близок, оставляя в то же время открытым вопрос о Лачине, Кельбаджаре и Шуше до окончательного политического решения. Лавров ясно дал понять, что ценой такого решения будет размещение российских миротворцев.

Более 25 лет Азербайджан отвергал идею развертывания в зоне конфликта российского миротворческого контингента, поскольку это привело бы к сохранению режима Нагорного Карабаха и замораживанию конфликта еще на одно поколение. Преимущество, полученное Азербайджаном при поддержке Турции, было бы растрачено впустую вместе с современными вооружениями, которые принесли военный успех. Алиев не удосужился ответить на предложение Лаврова. Переговоры, последовательно проводившиеся россиянами, французами и американцами, привели к «гуманитарным» прекращениям огня, которые нарушались иногда в считанные минуты по мере того как Азербайджан продолжал наступление. Алиев отверг призывы выражавшего озабоченность международного сообщества, заявив, что он всего лишь обеспечивает выполнение резолюций Совета Безопасности ООН, неодно- 
кратно принимавшихся начиная с 1993 года, когда армянские наступательные действия привели к захвату значительной части территории Азербайджана и перемещению населения ${ }^{195}$.

Армения и Нагорный Карабах, которые в течение многих лет не обращали внимание на наращивание азербайджанского военного потенциала, так и не нашли эффективного ответа на быстрое наступление Азербайджана. Премьер-министр Пашинян обратился к Путину за помощью, но 31 октября получил холодный ответ не от Путина, а от МИД России, в заявлении которого была повторена стандартная позиция о том, что если сама Армения подвергнется нападению, то Россия выполнит свои союзнические обязательства в рамках Договора о коллективной безопасности. В то же время Россия призвала все стороны конфликта соблюдать режим прекращения огня, о котором они договорились в Москве 10 октября ${ }^{196}$. Россия вновь оказалась перед дилеммой своей политики на Южном Кавказе: как обеспечить баланс в отношениях с Арменией и Азербайджаном, сохраняя влияние на обе стороны и при этом сводя к минимуму дестабилизирующие последствия их политики.

Судя по всему, Россия не была готова поддержать Пашиняна, который, как лидер «цветной революции», не пользуется популярностью у российских СМИ. Придя к власти, Пашинян попытался заверить Путина в том, что он «рассматривает демократию как твердое убеждение, а не как геополитическую ориентацию, и четко разделяет эти понятия» ${ }^{197}$. Возможно, это заявление не убедило Путина, но трудно поверить, что неприязненное отношение к одному из лидеров могло разрушить российско-армянский союз, складывавшийся на протяжении поколений. Более вероятно, что Путин увидел в этой ситуации возможность добиться большего - стратегического партнерства с Азербайджаном, позволив Алиеву достичь ряда его военных целей. Если бы это разрушило надежды Нагорного Карабаха на объединение с Арменией или независимость, Армения оказалась бы в затруднительном положении. Ее безопасность по-прежнему зависела бы от России, что наглядно продемонстрировала турецкая военная политика в Азербайджане. Путин уже создал похожий прецедент: в 2003 году он был готов пожертвовать своими приднестровскими подопечными, когда Молдова проявила готовность на основе меморандума Козака согласиться с российским военным присутствием в стране и сменить геополитическую ориентацию.

Вовлечение Турциии в карабахскую войну обозначило резкое изменение прежней политики страны. Бывший президент Сулейман Демирель говорил, что войти в Карабах можно за считанные минуты, а на то, чтобы выйти, уйдут годы. Несмотря на все рассуждения о «неоосманской» стратегии президента Реджепа Тайипа Эрдогана, его решения в пользу вмешательства всякий раз носят конъюнктурный характер, если складывающаяся ситуация обещает возможность расширить присутствие и влияние Турции. В Турции сильна общественная поддержка Азербайджана. Эрдогана, возможно, побудили к действиям заявления Армении в августе 2020 года о необходимости вернуться к Севрскому договору 1920 года ${ }^{198}$. Других серьезных моти- 
вов для вмешательства у Турции нет. Она уже имеет автомобильные и железнодорожные коммуникации, соединяющие ее с Арменией, Азербайджаном и Центральной Азией через Грузию. Ежегодный турецкий экспорт в Армению, составляющий 248 млн долларов США, вряд ли заметно вырастет, а если он и прекратится, на это вряд ли кто-то обратит внимание ${ }^{199}$.

Франция и США, западные сопредседатели Минской группы, уступившие инициативу России, пытались посредничать в переговорах о прекращении огня, но мало что сделали после их срыва. Пассивность западных держав обеспечила и России, и Турции больше пространства для маневра.

\section{Прекращение огня и его последствия}

На протяжении десятилетий Азербайджан отклонял требования России о развертывании в зоне конфликта миротворческих сил. Почему же тогда 9 ноября Алиев принял российский план прекращения огня, который предусматривал развертывание 1960 миротворцев с военной техникой? ${ }^{200}$ В военном отношении азербайджанская армия вполне могла взять как Лачин, отрезав тем самым Нагорный Карабах от Армении, так и Степанакерт, его столицу. Перспектива появления еще 80000 армянских беженцев вряд ли могла волновать Алиева, которому все еще приходится иметь дело с примерно 850000 азербайджанских беженцев и внутренне перемещенных лиц, появившихся в результате военных действий в Карабахе и вокруг него в начале 1990-х годов 201 .

Чтобы ответить на этот вопрос, мы должны сначала разобраться, какие задачи решают миротворцы. Во-первых, в течение пяти лет (с возможностью продления мандата) они призваны обеспечивать гарантии безопасности Нагорного Карабаха, независимо от того, будет ли достигнуто соглашение о его статусе. Во-вторых, они позволяют Москве проецировать свою силу на весь Южный Кавказ, что является давней целью России. В-третьих, российские миротворцы будут контролировать транспортное сообщение между Нагорным Карабахом и Арменией. Российские пограничники будут контролировать транспортное сообщение между азербайджанским эксклавом Нахичевань и основной частью Азербайджана через Мегринский район Армении. Они также могут контролировать железнодорожное сообщение между Арменией и Ираном, осуществляемое по железнодорожному мосту через реку Аракс в Джульфе в Нахичевани. Эти функции усилят российское влияние на торговлю и экономику региона.

Почему же тогда Алиев остановил наступление и согласился на такое расширение российского влияния? Мы пришли к выводу о том, что Путин (и, возможно, Эрдоган) оказал на него достаточно сильное давление. Не исключено, что у Путина уже была договоренность с Эрдоганом. Вполне вероятно, Путин что-то обещал Алиеву, чтобы заручиться его согласием. Стабильность перемирия будет зависеть 
от того, как Россия будет соблюдать секретные обещания и договоренности, но у нас нет фактов, позволяющих утверждать, что такие договоренности были. Мы можем сделать вывод о том, что были разногласия относительно роли Турции. Алиев наверняка исходил их того, что Турции должна быть отведена такая же роль, как и России. Россия же готова была согласиться лишь на незначительное техническое содействие со стороны Турции ${ }^{202}$. Россия и Турция все еще обсуждают реализацию достигнутых ими договоренностей. Россия пока добилась своего, но если Эрдоган сочтет, что отведенная ему роль не является достойной, он вряд ли останется пассивным.

Лавров ясно дал понять, что Россия будет добиваться одобрения перемирия Советом Безопасности ООН, что, как минимум, означало бы одобрение развертывания российских миротворческих сил и препятствовало бы изменению их состава ${ }^{203}$. Со времени инициативы Медведева вплоть до 2016 года, включая «казанскую формулу», Россия, похоже, соглашалась с перспективой развертывания в зоне конфликта многонациональных нейтральных сил по поддержанию мира под эгидой ОБСЕ, которая определяла бы их численность и состав командования, с тем чтобы не допустить монополизации миротворческой функции какой-либо одной страной. Однако после азербайджанского наступления в апреле 2016 года Лавров попытался оказать давление на Азербайджан и Армению, с тем чтобы они согласились на развертывание российских сил по поддержанию мира. О приоритетах России говорит то обстоятельство, что наиболее подробно разработаны те положения нынешнего плана прекращения огня, которые оговаривают российское военное присутствие в регионе и не предусматривают миротворческую роль ОБСЕ. Одно из потенциальных последствий расширения роли России, которая замораживает новую линию фронта состоит в том, что если раньше лидеры Азербайджана и Армении видели в Минской группе козла отпущения, который должен был публично взять на себя вину за их собственную неспособность достичь мира, то теперь (особенно в Азербайджане) они могут переложить эту ответственность на Россию и ее миротворцев.

\section{Перспективы переговоров}

В соглашении о прекращении огня нет ни слова о будущих переговорах о статусе Нагорного Карабаха. Алиев торжественно заявил об этом в своем обращении к народу 10 ноября ${ }^{204}$. В конечном счете, однако, если на неопределенное время оставить лишившийся части территории Нагорный Карабах без какого-либо статуса, то это создаст проблемы в будущем. Азербайджан, возможно, еще не готов принять карабахцев в свое лоно, предоставив им «высокую степенью автономии», а карабахцы, возможно, слишком ожесточены и не намерены сотрудничать с Азербайджаном. Но в конечном счете возобновление транспортного сообщения и торговых связей поставит в повестку дня практические вопросы, ответы на которые нужно будет 
обсуждать за столом переговоров. Баку может утверждать, что, поскольку война с Арменией закончилась, теперь это - внутренний вопрос Азербайджана (используя в качестве прецедента прекращение Россией мандата Группы содействия ОБСЕ в Чечне после того, как Москва сделала выбор в пользу военного решения). Однако Россия и другие страны могут повлиять на Азербайджан, с тем чтобы он начал переговоры при международном посредничестве.

Если такие переговоры начнутся, Россия уже дала понять, что не допустит изменений в их формате на основе Минской группы ${ }^{205}$. Как упоминалось выше, Россия уже более десяти лет доминирует в этом формате. Очевидно, что, сохраняя его, Россия рассчитывает сохранить и свое доминирующее положение в нем. Сохранение прежнего формата предпочтительнее по сравнению с наиболее часто предлагаемыми альтернативами: заменой нынешних сопредседателей другими, не называемыми странами, включение в состав участников переговоров карабахских армян или подключение Турции в качестве еще одного сопредседателя. Любая из этих альтернатив будет мешать ведению переговоров:

- Новым сопредседателям пришлось бы потратить немало времени и усилий для того, чтобы вжиться в эту роль. Нынешним сопредседателям следует поддерживать более тесную связь с другими участниками Минской группы, включая Турцию и Швецию (последняя будет председательствовать в ОБСЕ в 2021 году). Более интенсивная коммуникация позволит сделать процесс посредничества более транспарентным, но не изменит баланс внутри Группы.

- Карабахские армяне, чьи лидеры правили Арменией с 1998 по 2018 год, были хорошо представлены на переговорах того времени. Армения неоднократно требовала подключения представителей Нагорного Карабаха к переговорам в качестве самостоятельной стороны не для того, чтобы способствовать урегулированию, а чтобы получить дополнительные аргументы в пользу международного признания Карабаха и избавить саму Армению от обвинений в срыве компромиссных договоренностей. В ходе новых переговоров карабахцы могут либо заменить Армению (если стороны согласятся, что это внутренний конфликт с международными последствиями), либо занять место в составе армянской делегации (давая понять, что этот конфликт остается международным).

- Придание Турции статуса сопредседателя имело бы токсичные последствия, дав отстаивающим линию на ирредентизм сторонникам жесткой линии из армянской диаспоры на Западе, чьи предки подверглись геноциду со стороны османских турок, моральное право вето в отношении позиции, которую Армения займет на переговорах.

Звучат предложения перенести переговоры на площадку ООН, чтобы придать им новый импульс. Однако для этого пришлось бы преодолеть ряд препятствий, включая возражения некоторых заинтересованных сторон и существование четырех резолюций Совета Безопасности ООН, которые, по мнению Азербайджана, оправды- 
вают его военные действия ${ }^{206}$. Такое решение подкрепило бы желание России добиться принятия еще одной резолюции Совета Безопасности ООН, которой было бы одобрено развертывание ее миротворцев. Такое решение усилило бы международно-правовую легитимацию российского присутствия в регионе. К тому же нет оснований полагать, что ООН с бо́льшим успехом могла бы повлиять на позиции лидеров Армении и Азербайджана, чем государства-сопредседатели Минской группы, являющиеся постоянными членами Совета Безопасности.

Звучали и призывы к созыву Минской конференции (в ней приняли бы участие все члены Минской группы), проведение которой планировалось в 1992 году, но этому помешали последовательные возражения сторон. Именно невозможность провести конференцию привела к появлению современного института сопредседателей. Как правило, считается, что созыв конференции имел бы смысл только для завершения работы над текстом политического соглашения, в основном уже согласованного сторонами, и для одновременного проведения конференции доноров в интересах содействия стабилизации послевоенной ситуации. Если бы конференция была созвана преждевременно, то она могла бы превратиться в площадку для неконструктивных взаимных упреков, которые уже звучат в Постоянном совете ОБСЕ. Еще один постоянно предлагаемый вариант - признание Арменией независимости Нагорного Карабаха. Это могло бы поднять моральный дух армян, но данный жест не имел бы никаких иных последствий ${ }^{207}$.

\section{Будущее Минской группы}

Мы полагаем, что в условиях заключенного при посредничестве России соглашения о прекращении огня роль Минской группы ОБСЕ могла бы заключаться в следующем: в ведении переговоров между сторонами о мерах укрепления доверия и безопасности (МДБ), будущем статусе Нагорного Карабаха и деталях регионального соглашения о мире.

Обсуждение МДБ должно начинаться с мер, которые сделали бы регион безопасным для его нынешних жителей и обеспечили бы возвращение внутренне перемещенных лиц. США и ЕС вряд ли согласятся направить сюда крупные гражданские миссии по оказанию содействия или предоставить финансовую помощь, не имея возможности контролировать ее использование Россией, Арменией и Азербайджаном. ОБСЕ следовало бы учредить здесь свое присутствие для согласования и осуществления проектов, необходимых как для оставшегося, так и для возвращающегося в регион населения. Это присутствие могло бы продолжить деятельность бюро личного представителя действующего Председателя или стать его преемником. Помимо реализации проектов, связанных с общими вопросами оказания гуманитарной помощи в целях восстановления домов и критической инфраструктуры присутствие могло бы содействовать решению таких задач, как: 
- разминирование;

- разъединение и вывод войск и тяжелых вооружений;

- полицейская деятельность и подготовка кадров полиции;

- возможная в будущем роль ОБСЕ в военном или гражданском наблюдении за прекращением огня;

- создание транспортной инфраструктуры для передвижения гражданских лиц через линию соприкосновения, включая транспортное сообщение между Арменией и Нагорным Карабахом;

- обсуждение с участием Управления Верховного комиссара ООН по делам беженцев и Международным комитетом красного креста вопросов оценки потребностей в оказании гуманитарной помощи оставшемуся в Нагорном Карабахе армянскому населению и возвращающимся сюда внутренне перемещенным лицам - азербайджанцам;

- защита и восстановление объектов религиозного и культурного наследия в регионе $^{208}$;

- организация рынков для каждой из сторон, имея в виду организовать на более позднем этапе рынки, доступные для обеих сторон;

- создание совместных рабочих групп для налаживания сотрудничества, необходимого для решения вопросов развития инфраструктуры, здравоохранения, функционирования банковской системы;

- осуществления деятельности, в том числе по линии гражданского общества, направленной на сдерживание враждебной риторики. На первых порах рассчитывать на успех такой деятельности сложно, но важны даже маленькие шаги в этом направлении. Со временем эта деятельность могла бы быть расширена и включать совместные программы, ориентированные на гражданское общество, к примеру, на молодых лидеров.

Переговоры о будущем статусе Нагорного Карабаха и его жителей будут долгими и трудными. Перемирие цементировало новые линии соприкосновения. Обеим сторонам, которые еще раз убедились в том, что военным путем можно изменить ситуацию на местах, понадобится время, чтобы смириться с новым равновесием. Но это не дает передышку западным участникам Минской группы - не только США и Франции, но и Германии, Турции и Швеции. Для того, чтобы проявить свои интересы и внести участие более широкого международного сообщества им необходимо сотрудничать в разработке альтернативы перспективному российскому плану, который неизбежно будет содержать положения, закрепляющие российское присутствие в регионе. Самая важная часть подготовки к такой работе - прислушаться к заботам населения во всем регионе. В целом лица, принимающие решения во всех внешних державах (включая Турцию и Россию), нуждаются в лучшем понимании истории, культуры и народов этих стран. 
Для нормализации отношений в первую очередь между Арменией и Азербайджаном, а также для открытия международных границ, например, между Турцией и Арменией, необходимо региональное мирное соглашение. Подписав учредившие СНГ Алма-Атинские протоколы от 21 декабря 1991 года, Армения и Азербайджан наряду с другими республиками Советского Союза договорились о признании независимости друг друга в пределах существовавших в советское время границ. Но карабахский конфликт уже вступал в фазу полномасштабных военных действий, и обе страны так и не установили отношения и не договорились о границах. Азербайджан считал карабахский конфликт военной агрессией со стороны Армении, а Армения азербайджанской агрессией против населения Нагорного Карабаха. Действия России в 2014 году в Крыму и на востоке Украины с их последствиями для Алма-Атинских протоколов еще больше усложнили ситуацию.

В качестве первого шага Минская группа должна попытаться выступить посредником в достижении официальной договоренности о прекращении огня на границе Азербайджана с Арменией. Это особенно необходимо с учетом перспективы возвращения азербайджанских внутренне перемещенных лиц в их прежние дома в граничащих с Арменией Кельбаджарском и Лачинском районах. На границе происходили столкновения, последний раз - в июле 2020 года. Прекращение огня может создать предпосылки для дальнейшего развития отношений.

Региональное соглашение могло бы также включать положение о полном открытии сухопутной границы между Арменией и Турцией. С советских времен из Карса в Турции в Ленинакан (ныне Гюмри) в Армении раз в неделю ходил поезд. В 1993 году Турция выделила средства на обеспечение трансграничного автомобильного и грузового сообщения. Однако мартовское наступление 1993 года на Кельбаджар, частично организованное с территории Армении, заставило Турцию прекратить железнодорожное и отменить планы организации автомобильного сообщения. Попытки нормализации отношений в 2009 году, решительно поддержанные США, встретили противодействие со стороны ключевых групп населения. С возвращением Кельбаджарского района под контроль Азербайджана исправлена ситуация, ставшая поводом для закрытия этой границы. Восстановление трансграничного сообщения стало бы первым шагом на пути к общей нормализации отношений.

\section{Заключение}

Недавние боевые действия ознаменовали разрыв с психологией последних 26 лет. Впервые с момента прекращения огня в 1994 году и Баку, и Ереван теперь осознают, что политических целей можно достичь с помощью военной силы. Обе столицы привыкли к мысли о том, что военное противостояние зашло в тупик, и адаптировали свои стратегии к этому умонастроению. Военные действия в прошлом были не стратегическими, а демонстративными и преследовали цель не изменить ситуацию 
на местах существенным образом, а произвести впечатление на внутреннюю и (или) международную аудиторию. К такому образу мышления уже не вернуться. Российские миротворцы могут предотвратить возобновление военных действий, но не могут искоренить идею обеих сторон о том, что их возобновление в будущем может снова изменить баланс.

По этой причине настоятельно необходимо возобновить многосторонние переговоры. Переговоры, проводимые в одностороннем порядке, например, Россией, или в рамках тайного сотрудничества, например, с Турцией, не могут в полной степени обеспечить интересы ни противоборствующих сторон, ни их народов. Минской группе как институту международного сотрудничества - ее сопредседателям при поддержке всех других участников - необходимо быть на высоте ее ответственности, укрепить доверие и безопасность в отношениях между комбатантами, совместно сформулировать и согласовать со сторонами новые планы по достижению справедливого и прочного мира во всем регионе.

\section{Примечания}

183 Авторы хотят поблагодарить членов экспертной комиссии, коллег из организаций-членов и других доверенных коллег, с которыми мы поделились проектами настоящего доклада и которые предоставили ценную информацию на каждом этапе.

184 Терминологическое примечание. Согласно де Ваалу, термин «Нагорный Карабах» обозначает административно-политическое образование, называвшееся в советское время Нагорно-Карабахской Автономной Областью (НКАО), известное сегодня на армянском языке как Арцах. См.: de Waal T. Black Garden. - New York; London: New York University Press, 2003. «Армения» обозначает Республику Армения. «Карабахский конфликт» обозначает конфликт, начавшийся в 1988 году после того как Верховный Совет НКАО обратился к советским властям с просьбой о передаче НКАО из состава советского Азербайджана в состав советской Армении.

185 Резолюции Совета Безопасности ООН 822 (30 апреля 1993), 853 (29 июля 1993), 874 (14 октября 1993), 884 (12 ноября 1993).

186 Libaridian J. Why Negotiations Failed // Armenian Mirror-Spectator. 2020. 2 November 2020. URL: https://mirrorspectator.com/2020/11/02/why-negotiations-failed/.

187 См., к примеру: Remler Ph. Chained to the Caucasus. - Washington: IPI, 2016. URL: https://w ww.ipinst.org/wp-content/uploads/2016/05/1605-Chained-to-the-Caucasus.pdf.

188 Этим документом не предусмотрено содержательного решения вопроса, а только прекращение военных действий: обращение премьер-министра к народу // Официальный сайт Премьер-министра Республики Армения. 2020. 12 ноября. URL: https://www.primeminister. am/ru/statements-and-messages/item/2020/11/12/Nikol-Pashinyan-Speech/.

189 «Поэтапный подход ... не может служить основой для урегулирования». Из письма Роберта Кочаряна сопредседателям Минской группы, начало 1998 года (без даты).

190 Алиев исключил какой-либо особый статус для Нагорного Карабаха // ТАСС. 2020. 17 ноября. URL: https://tass.ru/mezhdunarodnaya-panorama/10023751.

191 Пост Ильхама Алиева в Facebook от 8 ноября 2020. URL: https://www.facebook.com/Preside ntIlhamAliyev/photos/a.10151996474470315/10164122626875315/. 
192 См., в частности: После карабахского конфликта все говорят о «революции дронов» // Медуза. 2020. 19 ноября URL: https://meduza.io/feature/2020/11/19/posle-karabahskogo-konflikta -vse-govoryat-o-revolyutsii-dronov; Erdoğan: Dağlık Karabağ'da çözüm vakti geldi // Deutsche Welle Türkçe. 2020. 29 сентября 2020. URL: https://www.dw.com/tr/erdo.

193 Fahim K., Khurshudyan I., Zakaria Z. Deaths of Syrian mercenaries show how Turkey, Russia could get sucked into Nagorno-Karabakh conflict // Washington Post. 2020. 14 October 2020. URL: https://www.washingtonpost.com/world/middle_east/azerbaijan-armenia-turkey-nagornokarabakh/2020/10/13/2cdcale6-08bf-11eb-8719-0df159d14794_story.html.

194 Лавров призвал ввести миротворцев в Нагорный Карабах // Regnum. 2020. URL: https://reg num.ru/news/polit/3089582.html; Интервью Министра иностранных дел Российской Федерации С.В.Лаврова радиостанциям «Sputnik», «Комсомольская правда» и «Говорит Москва», Москва, 14 октября 2020 года // Официальный сайт МИД РФ. 2020. 14 октября. URL: https://www.mid.ru/ru/press_service/minister_speeches/-/asset_publisher/7OvQR5KJWV $\mathrm{mR} /$ content/id/4381977.

195 Пост Ильхама Алиева в Facebook от 8 ноября 2020. URL: https:/www.facebook.com/Preside ntIlhamAliyev/photos/a.10151996474470315/10164085858605315.

196 Заявление МИД России в связи с обращением Премьер-министра Республики Армения Н.В. Пашиняна к Президенту Российской Федерации В.В.Путину // Официальный сайт МИД РФ. 2020. 31 октября. URL: https://www.mid.ru/ru/press_service/spokesman/official_stat ement/-/asset_publisher/t2GCdmD8RNIr/content/id/4411939.

197 Zolyan M. Сможет ли «Новая Армения» отделить демократические преобразования от геополитики? // OC Media. 2018. 30 июля. URL: https://oc-media.org/ru/statyi/analitika-smozh et-li-novaya-armeniya-otdelit-demokraticheskie-preobrazovaniya-ot-geopolitiki/.

198 Липаритян Ж. Шаг, на этот раз большой шаг назад // Aravot. 2020. 2 сентября. URL: https:// www.aravot-ru.am/2020/09/02/335325/. По условиям Севрского договора союзные державы, одержавшие победу в Первой мировой войне, планировали разделить Османскую империю. Договор так и не был ратифицирован. Последующие договоры, подписанные различными сторонами Севрского договора, в том числе Арменией (Карсский договор 1921 года), поставили его положения под вопрос. Лозаннский договор 1923 года между Турцией и союзниками заменил Севрский и стал учредительным документом Турецкой Республики.

199 Armenia // The Observation of Economic Complexity. URL: https://oec.world/en/profile/country /arm.

200 Заявление Президента Азербайджанской Республики, Премьер-министра Республики Армения и Президента Российской Федерации // Официальный сайт Президента Российской Федерации. 2020. 10 ноября. URL: http://kremlin.ru/events/president/news/64384.

201 Azerbaijan: Analysis of Gaps in the Protection of Internally Displaced Persons (IDPs). UNHCR; the European Commission, October 2009. P. 3. URL: https://www.unhcr.org/4bd7edbd9.pdf.

202 Ильхам Алиев, «Ильхам Алиев и Президент России Владимир Путин встретились в режиме видеоконференции» // Facebook. 2020. 10 ноября. URL: https://www.facebook.com/Presid entIlhamAliyev/videos/831550284329696; Интервью Министра иностранных дел Российской Федерации С.В.Лаврова российским и иностранным СМИ по актуальным вопросам международной повестки дня, Москва, 12 ноября 2020 года // Официальный сайт МИД РФ/2020. 12 ноября 2020. URL: https://www.mid.ru/web/guest/foreign_policy/international_sa fety/conflicts/-/asset_publisher/xIEMTQ3OvzcA/content/id/4429844.

203 Там же.

204 Ильхам Алиев, «Ильхам Алиев обратился к народу»// Facebook. 2020. 10 ноября 2020. URL: https://www.facebook.com/PresidentIlhamAliyev/videos/402316387790506. 
205 См., например: Интервью Министра иностранных дел Российской Федерации С.В.Лаврова российским и иностранным СМИ по актуальным вопросам международной повестки дня, Москва, 12 ноября 2020 года.

206 Ильхам Алиев, пост в Facebook от 31 октября 2020 года. URL: https://www.facebook.com/Pr esidentIlhamAliyev/photos/a.10151996474470315/10164085858605315/.

207 Президент России Путин, отвечая на вопросы прессы 17 ноября 2020 года, отчитал Армению за то, что она не последовала примеру России в Крыму: признав независимость Нагорного Карабаха, она затем могла бы добиться объединения и поставить международное сообщество перед свершившимся фактом. Однако большая часть международного сообщества осудила действия России в Крыму как нарушение международного права и ввела жесткие санкции, к которым гораздо меньшая по размеру экономика Армении была плохо подготовлена. См.: Ответы на вопросы СМИ по ситуации в Нагорном Карабахе // Официальный сайт Президента Российской Федерации. 2020. 17 ноября. URL: http://kremlin.ru/ev ents/president $/$ news $/ 64431$.

208 О телефонном разговоре Министра иностранных дел Российской Федерации С.В.Лаврова с Министром иностранных дел Азербайджанской Республики Д.А.Байрамовым // Официальный сайт МИД РФ. 2020. 15 ноября. URL: hhttps://www.mid.ru/web/guest/telefonnye-razg ovory-ministra/-/asset_publisher/KLX3tiYzsCLY/content/id/4434452. 